\title{
A Selective Review of Social Status Characteristics of Folk Dance Dancers and Their Family Members with Presentation of Gender Specificities
}

\author{
Jasna Popović ${ }^{1}$, Ružena Popović ${ }^{2}$, Vladimir Mutavdžić ${ }^{2}$ \\ ${ }^{1}$ Faculty of Sport and Physical Education, Leposavić, University of Pristine/Kos. Mitrovica (Kosovo), Serbia \\ ${ }^{2}$ Faculty of Sport and Physical Education, University of Niš, Niš, Serbia \\ Email address: \\ jasna.popovic@pr.ac.rs (J. Popović), ruzena@fsfv.ni.ac.rs (R. Popović), muta61@mts.rs (V. Mutavdžić)
}

\section{To cite this article:}

Jasna Popović, Ružena Popović, Vladimir Mutavdžić. A Selective Review of Social Status Characteristics of Folk Dance Dancers and Their Family Members with Presentation of Gender Specificities. International Journal of Education, Culture and Society.

Vol. 2, No. 2, 2017, pp. 38-49. doi: 10.11648/j.ijecs.20170202.11

Received: January 9, 2017; Accepted: February 6, 2017; Published: March 15, 2017

\begin{abstract}
In the present paper, using social identity and self-categorization theories as theoretical frameworks, we explore the role that social identity plays in affecting individual well-being of Folk-dance dancers, both Male (M) and Female (F) in Niš (Serbia). The status of manifest stratification variables were estimated on the Total sample of respondents $(\mathrm{N}=71)$, members of the Academic Cultural Artistic Ensemble "ORO", in Niš $(\mathrm{M}=33 ; \mathrm{F}=37)$. For the determination of social characteristics, the Questionnaire SSMIN (reduced), after model by [34] Saksida, Petrović, and Momirović (1972) was applied. The Questionnaire includes 5 sub-scales (with 15 items), and offered possibility of choosing alternative statements. The first scale explores the situation of the Folk-dance Dancers own, and their family members formal educational level; the second is relating to the basic residential status; the third scale evaluates the professional status. In line with predictions, social identification was significantly related to, and mediated the relationship between family group factors and individual wellbeing. The special issues as whole points to the capacity for a social identity approach to enrich academic understanding in these areas and provide a bridge between social-psychological concept, and some demographical and educational domains. On the base of obtained manifest variables data analysis it is possible to collect very important information for further studies with similar issues in the social domain.
\end{abstract}

Keywords: Social Identity, Folk Dance Dancers, Male/Female, Social Status, SSMIN Q, Gender Specificity

\section{Introduction}

The dance is a corporal practice of movements that involves different kinds of people of different ages, and their involvement reasons in practice are also different, as noted by [04] (Hirota et al., 2013). We cannot ignore that the dance classes involves the participants, making seek new possibilities of movement, giving them support to these new experience as was pointed by [10] (Motta et al., 2012).

"Term folk dance denoting any kind of dance which has been developed within a traditional community, rather than being created by a choreographer or teacher. Steps and patterns are passed from one generation to another, gradually undergoing change. .... In the past folk dances have exerted a strong influence on social and theatre dance, particularly during the Romanic period when they were considered to add both local and expressive color.... However, with urbanization, and demographic change many of the original dances have been lost, even though many Western countries, during the 20th century, attempted to re-discover and preserve these dances, often through specialist troupes of folk dancers. Even where they have survived, however, they are mostly staged as theatre or as tourist attractions rather than begin performed as genuine community events", as was described by Oxford Dictionary of Dance, p. 174 [03].

According to [41] (Wikipedia, the free encyclopedia) "Folk dances are dances that are developed by people that reflect the life of the people of a certain country or region. Not all ethnic dances are folk dances. The terms "ethnic" and "traditional" are used when it is required to emphasize the cultural roots of the dance. In this sense, nearly all folk dances are ethnic ones. Dances are usually held at folk dance 
gatherings or social functions by people with little or no professional training, often to traditional music. Dances not generally designed for public performance or the stage, though they may later be arranged and set for stage performances. Execution dominated by an inherited tradition from various international cultures rather than innovation (though folk traditions change over time). New dancers often learn informally by observing others and/or receiving help from others".

More controversially, some people define folk dancing as dancing for which there is no governing body or dancing for which there are no competitive or professional institutions. The term 'folk dance' is sometimes applied to dances of historical importance in European culture and history; typically originating before the 20th century.

The term 'folk dance' is reserved for dances which are to a significant degree bound by tradition and originated in the times when the distinction existed between the dances of 'common folk' and the dances of the 'high society'. A number of modern ballroom dances originated from folk ones“. The Kolo, or Oro, is danced primarily by people from Balkan region, and former Yugoslavia (Bosnia and Herzegovina, Croatia, Macedonia, Montenegro, Serbia, Bela krajina region of Slovenia), and Bulgaria.

It is performed amongst groups of people (usually several dozen, at the very least three) holding each other's having their hands around each other's waists (ideally in a circle, hence the name). There is almost no movement above the waist. The basic steps are easy to learn, but experienced dancers dance Kolo with great virtuosity due to different ornamental elements they add, such as syncopated steps. Each region has at least one unique Kolo; it is difficult to master the dance, and even most experienced dancers cannot master all of them. The dance is accompanied by traditional instrumental music, performed most often with an accordion, "frula", and "tamburica".

Many variations of Kolo are normally performed at weddings, social, and cultural ceremonies. The music is generally fast paced and contains tricky steps. Kolo costumes vary from region to region, but Bosnian and Serbian dance costumes typically are the most similar to each other. Generally, both men and women wear embroidered velvet vests. One of the most interesting components of the kolo costume is the shoes. The shoes are called "opanci", which are made from cured pig skin that is molded to fit the dancer's foot. The dance was used by Antonín Dvořák in his Slavonic Dances - The Serbian Kolo is the seventh dance from opus 72. [41] (From Wikipedia, the free encyclopedia).

Recent studies, elaborated by [11], [12] (Mutavdžić, V., 2000, 2007), are dealing with the factor structure of dance patterns in folk dances of Serbia, with application of adequate study design and advanced statistical data procession, and results evaluation.

The social environment comprising communities (families, neighborhoods, work teams, and various other forms of social groups) is not simply an external feature of the world that provides a context for individual behavior. Many studies have demonstrated that organizations exert a powerful impact on their members, but the mechanisms through which this occurs are not well understood. If groups provide individuals with a sense of meaning, purpose, and belonging (i.e. a positive sense of social identity) they tend to have positive psycho-social consequences.

In the present study, using social status, self-determination, and self-categorization theories as theoretical frameworks, we explore the role that social identity plays in affecting individual well-being of folk dance dancers, both male and female in city of Niš (the second large in Serbia), and the Academic Cultural Artistic Ensemble - AKUD "ORO", within academic society. The goal of the ensemble was to promote and provide interesting events to participants that encourage the practice of dance as artistic expression, with contribution to the dissemination of culture and personal development, and to encourage the emergence of new talent.

\subsection{Problem}

The performance of an individual on professional domain, as well as any sport or educational success is de facto result of developmental level of expressed psychosomatic dimensions, and the intensity and quality of interactive relations of those dimensions. Thus we can think about the situational conditions that sport and dance offer, and also how people define success and judge their level of performance, by [05] (Hirota et al., 2013).

Favorably social environment, limited simultaneously by impact of educational and cultural values, socialpolitical and economic characteristics of environment, enlarge the likelihood of an individual ability to transform under influence of educational process, sport or recreational training, and other different goals-oriented activities.

That, what is very close to various forms of dance activities, is the forming of the attitudes on social importance of folk dances, which is reflected primarily in the field of science, then in the artistic field, as well as tourist and economic area, as were observation, for the first time (during active on-site practical research, and publication work, up 1934 to 1963), and first defined by sisters Ljubica and Danica Janković, according to [20] (Popović, R., 1997). They have especially highlight the educational importance of folk dances based on the aspect of national-, social-, health related-, and esthetic-components, with the aim of forming versatile personality of individuals, and their positive social realization.

The current study, represents only a one segment of a more comprehensive research, which was elaborated in order to determine the structure of anthropological dimensions, of Folk dance Dancers, both male and female, by [20] (Popović, J., 2010). Therefore, the basic aim of this study was to evaluate the Social Identity of Folk dance Dancers, with identification of the status and characteristics of some manifest stratification variables in social field, as presented in reduced SSMIN Questionnaire, in relation to Gender differences. 


\subsection{Previous Researches Relative to Social Studies}

The initial debates were predominantly theoretically based, because of insufficiency of adequate theoretical [34] (Saksida, Momirović, Petrović, 1972) and mathematical models [33] (Saksida, and Knap, 1970), on which have to be based researches in domain of social identity and social status differences. At the end of $70^{\text {th }}$, and at the beginning of $80^{\text {th }}$ of the 20 th century, it has been developed, so far, the most applied model in region of the former SFR Yugoslavia, by [35] (Saksida, Petrović, 1973), and many others researches (Saksida, Caserman and Petrović, 1974; Knap, 1971; Momirović, and Knap, 1974; Petrović, and Hošek, 1974), which have contributed to the topic, and presented as Collection of papers by [12] (Petrović, and Hošek, 1986).

The largest number of the previous researches conducted, up $1964^{\text {th }}$ to $1986^{\text {th }}$, was conjoint in two part monograph publication: Contribution to the Sociology of Sport - $1^{\text {st }}$ [11] and $2^{\text {nd }}$ Book [12] by Editors: (K. Petrović, and A. Hošek, 1986). Mentioned authors established model, which was then followed by many sociologists, from East, as well as West countries, and served as stand for this very research, with necessary modifications within the content of some statements relative to SSMIN Q, because of changed socialpolitical situation in Region of former Yugoslavia, and our home country (Republic of Serbia).

The original Questionnaire (for adults) was applied by [28] Popović, and Purenović-Ivanović. The status of manifest stratification variables were established on the samples of examinees $(\mathrm{N}=60)$ of Physical Education female students of University of Niš $(n=41)$, and University of Pristine $(n=19)$. For the estimation of social characteristics, the Questionnaire SSMAX (after Saksida, Petrović \& Momirović, 1972) was applied. The Questionnaire includes 8 sub-scales (75 questions/items) with possibility of choosing offered alternative answers. The first (1) scale explore the statements of PE female students on their and close family members formal educational level; the second (2) is relating to the basic residential status; the third (3) evaluate the professional status, the fourth (4) evaluate social-political status, the fifth (5) scale evaluate the political orientation and activity, the sixth (6) give the information on basic economic status, the seventh (7) evaluate the life style, and the eights (8) give the information on sports status and activity of examined subjects. The special issues as whole points to the capacity for a social identity approach to enrich academic understanding in these areas and provide a bridge between social psychological concepts and the economic and educational domains.

\subsection{Previous Researches Relative to Dance Studies}

According to [09] (Meakin, and Sanderson, 1983, p. 82), authors principal concern in this article has been to "distinguish and briefly characterize four activities ("creative dance," "modern dance," "educational dance," and "modern educational dance"), which they have observed taking place under the title of dance, and its associated terminology in
English secondary schools. In addition, they have outlined, and discussed the main assumptions, beliefs, and values, or ideology that appears to underlie each of these activities. To prevent a misunderstanding, they add that these four activities were not consistently related to any particular agegroup, and that there was no developmental link between them. They also witnessed no hierarchical progression from one activity to another, nor do they advocate one. Authors noted that all four activities (though the first one only minimally) have potential for aesthetic education, while the third and fourth, if seriously pursued, can make a significant contribution to education in the arts, which is currently being denied the full attention it deserves in English schools. Authors agree that Dance can hardly be expected to flourish and make a significant educational contribution as long as those in charge fail to think carefully about aims, objectives, content, and methods and remain largely uninformed with the literature.

According to [36], (Sanderson, P., 2000), this research report describes the development of dance attitude scales, which were 'grounded' in the opinions of groups of 11-16year-old pupils in six schools throughout England. Factor analyses involving an initial sample of 368 male and female secondary school pupils produced four embryonic scales which were then tested with a sample of 1,668 adolescents. Satisfactory internal reliability coefficients were achieved and scale inter-correlations provided evidence of the scales as distinct measures. Further analyses undertaken to test validity employing data from the larger sample indicated that two of the four proposed scales (on Ballet in general, and on Male Dancers), may be valid measures of attitude, although less confidence can be placed in the third and fourth scales. Suggestions are made for the development and application of the inventory.

According to the study, done by Balter Blume, L., 2003, [01] in field of physical education (PE), using developmental, sociological, feminist, and dance studies perspectives on the social construction of body, sex, and gender, the author discusses the functions of organization and performance in the PE curriculum with specific attention to the embodied performance of culture through dance and movement. Classroom examples of critical and feminist approaches to dance pedagogy are provided to deconstruct body/sex/gender through dance education. A dialectical approach to critical self-reflection is proposed that limits reproduction of the $\mathrm{mind} /$ body split, thus rein scribing the body as subject.

According to review, elaborated by Risner, D. (2007), [31], Dance education experiences of boys and male youth are investigated in terms of dominant constructions of contemporary Western masculinity, and the potential limitations these hegemonic discourses may place on male participation. Recent research on boys and male youth in dance, although limited, suggests prevailing social stigma, hetero normative assumptions, narrow definitions of masculinity, and internalized homophobia in the field. From emerging research, this review essay explores the ways in which male youth in dance confront hetero-centric bias, 
gender norms, and gendered bodies, as well as peer pressure, and dominant cultural ideology in dance training, and education. Important points include key social questions of difference, pleasure, marginalization, and the larger effects and limitations of contemporary masculinity.

According to [38] paper, elaborated by (Sanderson, P., 2007) on the arts, social inclusion and social class, places the results of an empirical research study (when considering the case of dance), on the relationship between the social class factor and young people's perceptions of dance within the context of initiatives of British government, promoting social and educational inclusion through the arts. Four Likert-type dance attitude scales that were developed from pupil opinion expressed during prior discussions were included in a survey questionnaire, and responses sought from a nation-wide representative sample of 1298 11-16-year-old boys and girls. Analyses of the data showed that attitudes to aspects of dance varied with social class, and that there was an interaction between gender and social class in just one instance. A major implication of the research is that dance and the arts should be more widely available in schools so that all children and young people can have access to aesthetic experiences that have the potential to improve quality of life. It is concluded that the current limited provision within the National Curriculum may be contributing to the social and educational exclusion of some pupils.

According to empirical study, elaborated by [07] Koff, S. (2005), on Dance Education, it can be considered as an Aspect of Movement and Mobility in Everyday Living, when using the correct definition of dance education. Rather than referring to the rarified form of movement that we encounter on the concert stage, dance education is the education of our moving selves with the goal as self-expression. This can be initiated as an aspect of the initial developmental movement stages encountered by an infant through toddler stage, developed through early schooling in order to counteract the sedentary school lifestyle, and continued through adulthood as an aspect of keeping ourselves as fully integrated thinking, moving, and feeling human beings.

According to study, elaborated by [41] Vicario, T., and Chambliss, C. (2001), on the Benefits Associated with Dance Education for Adolescent Girls, authors suggest that Dance education provides an opportunity for aerobic exercise, and conditioning that is especially appealing to many girls. The benefits of taking dance classes were examined for girls, ages 13-20, enrolled in classes in three schools in Pennsylvania. Frequency distributions illustrated that the majority of dance students $(92 \%)$ reported that dance improved their discipline. Almost all dancers disagreed with the idea that dance made them hate their bodies; while $88 \%$ agreed that it helped them release their feelings. Almost all participants failed to report feeling anxious or worried at dance classes, and $77 \%$ felt better about themselves after dancing. The hypothesis that girls with greater dance experience would have higher selfesteem is somewhat supported by the results. The personality analysis revealed that extraverts made greater use of dance classes as a means of emotional expression. The parental support findings suggest that there is a congruence between girls' and their parents' attitudes toward this activity.

According to research study, elaborated by [02] (Bannon, F., Sanderson, P., 2000), authors have focused on experience which provides aesthetically significant dance education. This paper describes the breadth of emerging issues and concerns from current qualitative research study into dance education. The initial focus of the study has been to review the nature of aesthetic experiences in dance education, aiming to promote a coherent view of dance education as a distinct and humanizing pedagogy. Central to this approach is the development of the individual through increased aesthetic awareness, whereby opportunities are offered for the enhancement of reasoning processes with increasing perceptual and conceptual range in an atmosphere of exploration. In support of this, the concept of the aesthetic and its relevance to dance as part of an arts or humanities education profile is examined. The paper concludes by urging the adoption of a broad approach to qualitative research methodology, to investigate the issues revealed by the research study.

The review of qualitative research studies in available domestic literature indicates that dances are very popular recreational activities with young people. However, in many European educational institutions and schools dance is often regarded as that aspect of the PE curriculum most suited to young children and higher-primary school girls. This knowledge is not based on empirical information such are very rare details relating to adolescent attitudes to dance, and how these may vary with age and gender are spares. According to model, established by [37] (Sanderson, P. 2001), with application of Dance Attitude Scales, recant studies were elaborated in Serbia, and region wider, with the basic aim to estimate assumed differences in attitudes to different dances with adolescents of both gender, and different age. The opinions on the variety aspects of dance art were sought, therefore from relative unified sub-samples of 11-15-year-old children (boys and girls), from particularly urban schools in Serbia (Niš, Kruševac, Valjevo, Jagodina, Vršac, Grocka), Bosnia and Herzegovina (Tuzla), and Montenegro (Podgorica, Danilovgrad) using questionnaires which included Likert-tipe dance attitudes scales on Art Dance, Social Dance and Folk dance [17], (Popovic, R., Djordjevic, I., Dolga, M., Purenovic, T., Pavlovic, M., 2009). Analyses showed little change in attitudes between ages of 11-15 years old, and no interaction of age with gender. Girls displayed more positive attitudes than boys in first questionnaire (on the first and second segments) of the 4 applied scales. The absence of change in age-related scale in scores (in applied $\mathbf{Q}$ on Folk \& Social Dances) highlights the need for both: increased dance provision in schools and more focused teaching, with the specific nature of the genderrelated attitude differences offers curriculum development opportunities. The absence of interaction between age and gender suggests cultural rather than school influences on attitudes. The paradox of high levels of adolescent recreational and social interest in dance and the severely 
limited opportunities offered in schools for PE, and Dance education has received insufficient attention from curriculum innovators and researchers. It is generally accepted that the educational value of dances lie predominantly in their contribution to aesthetic development, but little is known about adolescent attitudes to dances as an aesthetic experience: the nature of extent of any male/female differences, for instance, whether these vary with the dance type, and if attitude change occurs between the ages of 11-15 years. The pilot study report was designed to provide such information in relation to Serbian urban school adolescents, concerning dances as curriculum activities in schools, which are relevant to many educationalists, first of all for Physical Education teachers, as well as for the other individuals of relevant culture institutions. The authors also hope that this study may provoke further work in the area, including crosscultural research programs, on the base of finding, elaborated by: [8], [17], [22], [23], [24], [25], [26], [29], and [30].

\section{Methods}

\subsection{Sample and Study Site}

The status of some social manifest stratification variables was estimated on the participants of the University Cultural Artistic Ensemble (AKUD) "ORO", both male, and female Folk dance dancers (FD) of Niš. Data collection occurred in the regular evening activity classes, during the period up April, $1^{\text {st }}$ to June, $20^{\text {th }}, 2010$, as part of broader research study which comprise also other segments of the anthropological dimensions of folklore dancers, not mentioned heir, such are: psychological characteristics (personal features and cognitive abilities), musical abilities, motor abilities, and social status, elaborated by [16] (Popović, J., 2010), within PhD study. The total sample was 71 dancers, starting age at 12-39-years-old.

\subsection{Instrument}

The phenomenological model of social stratification was applied for the social characteristics estimation using model according to Saksida, Petrović, and Momirović (1972). In this actual study was applied SSMIN (reduced version, includes 15 items), because of the study design limitations. This model predict three sub-systems in frame of ,social status", defined as: Social - Institutional - Consequential sub-system, but in current study was included only the first mentioned: 1. Social sub-system (responsible for an individual preparation to take certain position in the institutional sub-system of network roles:

(a) Educational status is responsible for the level, quality, and extent of subject's current or former completed education of dancers, as well as their family members.

(b) Basic residential status is responsible for the place of background of subjects and their close family members (father/mother/grandfather).

(c) Professional status is responsible for the structures of an individual qualification, which was admitted on the work place.

The Questionnaire SSMIN contents 15 (items/variables) within the first Scale of Social sub-system, divided in five scales: Variables for the evaluation of position in social subsystem: (1) educational level of subjects, father and mother (S/F/M); (2) qualification of subjects (S/F/M); (3) knowledge of foreigner languages of subjects $(\mathrm{S} / \mathrm{F} / \mathrm{M})$; (4) subject's actual or former sport activity (S/F/M); (5) characteristics of subjects former place of residency in childhood, until age of 15 years $(\mathrm{S} / \mathrm{F} / \mathrm{M})$.

\subsection{Procedures for Data Collection}

Prior to data collection with dancers, we ask permission from the (AKUD) supervisor to conduct the survey, so the Art Director signed a Letter of Authorization Institution. A Term of Free and Informed Consent Form, was signed to parents to allow their no mature children to participate in the study; along with the consent form, a letter of information to the participants was written, describing what procedures would be taken in data collection.

The procedures for data collection followed the Newsletter to Research Subjects and signature of the Terms of Consent, by paying attention to research ethics set by [42] (the Declaration of Helsinki, 196421, Resolution no. 466, WHO, 2002). Authors have adopted the division of the calculations of descriptive statistics separately by genders, and presented within the tables.

\section{Results and Interpretation}

\subsection{The Folk Dance Dancer's Social-Demographic Status}

Although the conducted survey has to be anonymous, due to the study design needs, the respondents were asked to give their own status as to age and gender, so there could be classified in four age categories, and there was also presented the indicators of average age of subjects within certain age categories, by gender, as well as a sample of Total (shown in Table 1). The total sample includes 71 dancers, divided in four Age-categories, of actual age up (12-40 years), presented in (Table 1), of which 34 were male folk-dancers $(47.9 \%)$, aged from 12 to 40 years old, and 37 were female (52.1\%), aged from 12 to 35 years old.

Table 1. The Folk-Dance Dancer's Age Categories both Male and Female.

\begin{tabular}{|c|c|c|c|c|c|c|c|c|c|}
\hline \multirow{2}{*}{$\frac{\text { Average Age }}{\text { Total }}$} & \multirow{2}{*}{$\frac{\text { Age }- \text { Categories }}{\text { Total }}$} & \multicolumn{2}{|c|}{ TOTAL $(\mathbf{N}=71)$} & \multicolumn{2}{|c|}{ Male-Dancers $(n=34)$} & \multicolumn{2}{|c|}{ Female-Dancers $(n=37)$} & \multicolumn{2}{|c|}{ Average Age (M/F) } \\
\hline & & $\mathrm{n}$ & $\%$ & $\mathrm{n}$ & $\%$ & $\mathrm{n}$ & $\%$ & $\mathrm{M}=34$ & $\mathrm{~F}=33$ \\
\hline 15.135 & c (12-19) & 23 & 32.39 & 7 & $20.59 \%$ & 16 & $43.24 \%$ & 14.27 & 16.0 \\
\hline 23.745 & $d(20-27)$ & 37 & 52.11 & 18 & $52.94 \%$ & 19 & $51.35 \%$ & 23.26 & 24.23 \\
\hline 31.905 & e $(28-35)$ & 10 & 14.08 & 8 & $23.53 \%$ & 2 & $5.4 \%$ & 28.81 & 35.0 \\
\hline 39.3 & $f(36-40)$ & 1 & 1.41 & 1 & $2.94 \%$ & $(-)$ & $(-)$ & 39.3 & $(-)$ \\
\hline
\end{tabular}




\subsection{The Parents Level of Completed Education}

In Table 2 is in detail displayed indicators as to the level of completed education of the respondent's parents (A-father's; B-mother's) in the socialization sub-system (according to replies of respondents) in total sample, and in sub-samples of folk-dance male $(\mathrm{M})$, and female $(\mathrm{F})$ dancers.

Gathered answers show that in total, when considering father school qualifications prevails 63.63\% (36.36\%; $27.27 \%$ ) completed a 4-years vocational school for nonproductive professions (3), while according to replies of female dancers, evidently is that prevails $(36.36 \%)$ university education of father (6), which is on second place $(48.48 \%)$, according to replies of both sub-samples $(12.12 \%, 36.36 \%)$.

Table 2. SOOM (1, 2) - Educational Level of Folk-Dancer's Parents: (A) Father; (B) Mother

\begin{tabular}{|c|c|c|c|c|c|c|c|c|c|c|}
\hline \multirow{3}{*}{$\begin{array}{c}\text { Item } \\
\text { Sample } \\
\text { Freq. }\end{array}$} & \multirow{3}{*}{$\begin{array}{c}\text { (A) Father } \\
\text { Total }(\mathbf{N}=66) \\
(\mathrm{f} / \%)\end{array}$} & \multicolumn{4}{|c|}{ Folk-Dancers } & \multirow{3}{*}{$\begin{array}{c}\text { (B) Mother } \\
\text { Total }(\mathrm{N}=68) \\
(\mathrm{f} / \%)\end{array}$} & \multicolumn{4}{|c|}{ Folk-Dancers } \\
\hline & & \multicolumn{2}{|c|}{ M-D $(n=33)$} & \multicolumn{2}{|c|}{ F-D $(n=33)$} & & \multicolumn{2}{|c|}{ M-D $(n=34)$} & \multicolumn{2}{|c|}{ F-D $(n=34)$} \\
\hline & & $\mathrm{n}$ & $\%$ & $\mathrm{n}$ & $\%$ & & $\mathrm{n}$ & $\%$ & $\mathrm{n}$ & $\%$ \\
\hline 1 & 1 & $(-)$ & $(-)$ & 1 & 3.03 & 1 & $(-)$ & $(-)$ & 1 & 2.94 \\
\hline 2 & 6 & 3 & 9.09 & 3 & 9.09 & 4 & 4 & 11.76 & $(-)$ & $(-)$ \\
\hline 3 & 21 & 12 & 36.36 & 9 & 27.27 & 26 & 11 & 32.35 & 15 & 44.12 \\
\hline 4 & 3 & 1 & 3.03 & 2 & 6.06 & 3 & 1 & 2.94 & 2 & 5.88 \\
\hline 6 & 16 & 4 & 12.12 & 12 & 36.36 & 17 & 8 & 23.53 & 9 & 26.47 \\
\hline 7 & 3 & 2 & 6.06 & 1 & 3.03 & 5 & 2 & 5.88 & 3 & 8.82 \\
\hline 8 & 2 & 1 & 3.03 & 1 & 3.03 & $(-)$ & $(-)$ & $(-)$ & $(-)$ & $(-)$ \\
\hline
\end{tabular}

Legend: (1) Primary School finished; (2) Complete Secondary School (3-years); (3) Complete Secondary trade school (4-years); (4) Secondary School Diploma (Gymnasia); (5) College; (6) High School Education (Faculty); (7) Specialization, master or PHD study complete; (8) Other

When considering mother's educational level collected answers show then in total sample, also prevails $(76.47 \%)$ completed a 4-years vocational school for non-productive professions (3), although it is evident that mothers have a higher level of education, compared to the fathers, when considering items $(5,6)$, in both sub-sample of the folk-dance dancers. Parent education is often stated in earlier researches as a functional element of nearly all other status characteristics. However, according to the study elaborated by Momirović \& Hošek, 1972 [12], these variables have only a moderate correlation $(.26-.30)$ with the system of other variables that could be attributed to their functional significance.

\subsection{The Proficiency Knowledge of a Foreign Language}

Pronouncement of respondents in terms of proficiency knowledge of a foreign language indicates that more than a half $(1 / 2)$ are able to use foreign language (2), as in male dancers $(55.9 \%)$, as well as in female dancers $(63.6 \%)$, although it is interesting the fact that about $1 / 3$ of the respondents have knowledge of two foreign languages (3), which is also relatively more pronounced among female dancers $(33.3 \%)$ than among male dancers $(29.4 \%)$.

Identical number of fathers in both, male (55. 9\%), and female dancer $(55.88 \%$ ) do not have knowledge of a foreign language (1), as well as mothers of male dancers (48. 5\%), completely different from mothers of female dancer, having knowledge $(48.5 \%)$ of a one foreign language (2). However, viewed on a total sample of respondents, in mothers prevails $(31 / 46.965 \%)$ knowledge of a foreign language (2), with an additional percentage $(3 / 9.09 \%)$ of those who use two foreign languages (3), compared to those who do not use a foreign language $(29 / 43.93 \%)$.

Table 3. JTOM (3, 4, 5) Knowledge of Foreign Languages: (1) Yourself- (2) Father - (3) Mother

\begin{tabular}{|c|c|c|c|c|c|c|c|c|c|c|c|c|c|c|}
\hline \multirow{3}{*}{$\frac{\text { Sample }}{\text { Item }}$} & \multicolumn{4}{|c|}{ Folk-Dancers } & \multicolumn{5}{|c|}{ Folk-Dancers } & \multicolumn{5}{|c|}{ Folk-Dancers } \\
\hline & \multicolumn{2}{|c|}{ Yourself (M) } & \multicolumn{2}{|c|}{ Yourself (F) } & \multirow[t]{2}{*}{$(\mathrm{N}=68)$} & \multicolumn{2}{|c|}{ Father (M) } & \multicolumn{2}{|c|}{ Father $(\mathrm{F})$} & \multirow[t]{2}{*}{$(\mathrm{N}=66)$} & \multicolumn{2}{|c|}{ Mother (M) } & \multicolumn{2}{|c|}{ Mother (F) } \\
\hline & $\mathrm{n}$ & $\%$ & $\mathrm{n}$ & $\%$ & & $\mathrm{n}$ & $\%$ & $\mathrm{n}$ & $\%$ & & $\mathrm{n}$ & $\%$ & $\mathrm{n}$ & $\%$ \\
\hline 1 & 3 & 8.82 & 1 & 3.09 & 38 & 19 & 55.88 & 19 & 55.88 & 29 & 16 & 48.48 & 13 & 39.39 \\
\hline 2 & 19 & 55.88 & 21 & 63.63 & 24 & 12 & 35.29 & 12 & 35.29 & 31 & 15 & 45.45 & 16 & 48.48 \\
\hline 3 & 10 & 29.41 & 11 & 33.33 & 5 & 3 & 8.82 & 2 & 5.88 & 6 & 2 & 6.06 & 4 & 12.12 \\
\hline 4 & 2 & 5.88 & $(-)$ & $(-)$ & 1 & $(-)$ & $(-)$ & 1 & 2.94 & $(-)$ & $(-)$ & $(-)$ & $(-)$ & $(-)$ \\
\hline
\end{tabular}

Legend: 1. No user; 2. Active user of one foreign language; 3 . Active user of two or more foreign languages; 4. No response

\subsection{The Educational Level of Respondents}

Looking on educational level of respondents in total (Table 4) and by sub-samples, in all is the most common finished secondary school/gymnasia (3), although more in a female dancers $(55.9 \%)$ than in male dancers $(38.2 \%)$, and a significant number of folk-dance dancers attended primary school $(22.06 \%)$, more in male dancers sub-sample $(32.35 \%)$ than in female folk-dance dancers $(11.76 \%)$. 
Table 4. SRSK (6) Folk-Dance Dancers Level of Education completed.

\begin{tabular}{clcccccc}
\hline Items & \multicolumn{1}{c}{ Folk-Dance Dancers (N=68) } & \multicolumn{2}{c}{ TOTAL } & \multicolumn{2}{c}{$(\mathbf{M})$ - Dancers $(\mathbf{n}=\mathbf{3 4})$} & \multicolumn{2}{c}{$(\mathbf{F})$ Dancers $(\mathbf{n}=\mathbf{3 4})$} \\
\hline & Statement's & $\mathbf{f}$ & $\mathbf{\%}$ & $\mathbf{n}$ & $\mathbf{\%}$ & $\mathbf{n}$ & $\mathbf{\%}$ \\
\hline 1. & Secondary Trade school (3-Years) & 3 & 4.41 & 2 & 5.88 & 1 & 2.94 \\
2. & Secondary Ordinary School (4-Years) & 16 & 23.53 & 7 & 20.59 & 9 & 27.27 \\
3. & Gymnasia, Secondary school (4-Years) & 32 & 47.06 & 13 & 38.23 & 19 & 55.88 \\
4. & Primary School & 15 & 22.06 & 11 & 32.35 & 4 & 11.76 \\
5. & No response & 2 & 2.94 & 1 & 2.94 & 1 & 2.94 \\
\hline
\end{tabular}

\subsection{The Occupation of Parents}

Looking the qualification of parents (Table 5), it is evident large disparity of responses, according to individual statements, which are in total of 13 . Relatively (\%) the most represented is $(20.6 \%)$ unemployment of the mothers (1) within the male dancers, with an equal number $(17.65 \%)$ of professional (5), highly qualified (6), and workers with higher education in public activities/civil servant (10) for father's occupations, followed by the worker with an university education (12), which is represented with $11.76 \%$.

Within female dancer is the most represented occupation highly qualified worker (6) with $(24.2 \%$ for male dancers, and $21.2 \%$ for the female dancers), as well as in total $(22.72 \%)$. Significantly increasing number of mothers is unemployed (15.15\%), compared with fathers $(9.09 \%)$. Then, as the next options to the number of responses, in total $(16.66 \%)$, and in male dancers $(21.21 \%)$ and female dancer $(12.12 \%)$ occurred occupation technical staff with secondary professional education (7) and a civil servant with secondary education (8) for father's occupation is represented with $12.12 \%$. This dispersion of responses indicates the fact that the qualification acquired in previous education, is not in large correlation with actual, or recognized qualifications, viewed in terms of parents' occupation.

Table 5. KVOM (7, 8) Occupation of Parent - (7) Father; Occupation of Parent- (8) Mother.

\begin{tabular}{|c|c|c|c|c|c|c|c|c|c|c|c|c|c|}
\hline \multirow[b]{3}{*}{ Items } & \multirow[t]{2}{*}{ Total / Sub-samples } & \multicolumn{8}{|c|}{ Male Dancers $(n=34)$} & \multicolumn{4}{|c|}{ Female Dancers $(n=33)$} \\
\hline & & \multicolumn{2}{|c|}{ Total } & \multicolumn{2}{|c|}{ Father } & \multicolumn{2}{|c|}{ Mother } & \multicolumn{2}{|c|}{ Total } & \multicolumn{2}{|c|}{ Father } & \multicolumn{2}{|c|}{ Mother } \\
\hline & Abs/Rel. Freq. & 68 & $\%$ & $\mathrm{n}$ & $\%$ & $\mathrm{n}$ & $\%$ & 66 & $\%$ & $\mathrm{n}$ & $\%$ & $\mathrm{n}$ & $\%$ \\
\hline 1 & Unemployed & 9 & 13.23 & 2 & 5.88 & 7 & 20.59 & 8 & 12.12 & 3 & 9.09 & 5 & 15.15 \\
\hline 2 & Non-qualified laborer & - & - & - & - & - & - & 2 & 3.03 & 1 & 3.03 & 1 & 3.03 \\
\hline 3 & Semi-qualified laborer & 3 & 4.41 & 2 & 5.88 & 1 & 2.94 & - & - & - & - & - & - \\
\hline 5 & Professional worker & 11 & 16.17 & 6 & 17.65 & 5 & 14.71 & 4 & 6.06 & 1 & 3.03 & 3 & 9.09 \\
\hline 6 & High qualified worker & 10 & 14.71 & 6 & 17.65 & 4 & 11.76 & 15 & 22.72 & 8 & 24.24 & 7 & 21.21 \\
\hline 8 & Civil servant with Secondary school & 5 & 7.35 & 3 & 8.82 & 2 & 5.88 & 6 & 9.09 & 4 & 12.12 & 2 & 6.06 \\
\hline 9 & Laborer with higher school in trade profession & 1 & 1.47 & 1 & 2.94 & - & - & 3 & 4.54 & 2 & 6.06 & 1 & 3.03 \\
\hline 10 & Laborer with higher school in civil services & 9 & 13.23 & 6 & 17.65 & 3 & 8.82 & 6 & 9.09 & 3 & 9.09 & 3 & 9.09 \\
\hline 11 & Laborer with Faculty in trade profession & 4 & 5.88 & 2 & 5.88 & 2 & 5.88 & 4 & 6.06 & 1 & 3.03 & 3 & 9.09 \\
\hline 12 & Laborer with Faculty in civil services & 9 & 13.23 & 4 & 11.76 & 5 & 14.71 & 3 & 4.54 & 1 & 3.03 & 2 & 6.06 \\
\hline 13 & No response & 1 & 1.47 & - & - & 1 & 2.94 & 4 & 6.06 & 2 & 6.06 & 2 & 6.06 \\
\hline
\end{tabular}

\subsection{The Education of the Grandfather}

Considering of the grandfather degree of Education - by the father-side (Table 6), identical in total sample (25.37\%) were present a statements on completion of primary school (3) and completed craft (4), although in sub-sample of male dancers is the most represented $(32.35 \%)$ statement about completed craft, and in sub-sample of female dancer is the most common statement $(30.30 \%)$ on the completion of the primary school. In the sub-sample of the female dancers, by the frequency of the responses is the most significant statement about the completion of high school (6) in grandfather by mother side (21.21\%).
Considering of the grandfather degree of Education - by the mother-side (Table 6) the most often statement is on the completed craft (4) on the total (31.34\%), within sub-sample of male dancers $(35.29 \%)$, and female dancer $(27.27 \%)$. Second option by the frequency of statements in total sample $(17.91 \%)$, and within the sub-sample of male dancers (20.59\%) was completed college (6), while within the subsample of the female dancer $(18.18 \%)$ occurs response on completed faculty (7). When analyzing these numerical values, without application of advanced comparative procedures, it is only possible to highlight information that here is equally present relatively higher educational level of the grandfather by father-side, and mother-side within the sub-sample of female dancers. 
Table 6. $\operatorname{ODODM}(9,10)$ Education of Your Grandfather: (9) Father side; (10) Mother side.

\begin{tabular}{|c|c|c|c|c|c|c|c|c|c|c|c|c|c|}
\hline \multirow{3}{*}{$\begin{array}{c}\mathbf{N} \\
\text { Item }\end{array}$} & \multirow{3}{*}{$\begin{array}{c}\text { ODODM }(\mathbf{9 , 1 0 )} \\
\text { Sample } \\
\text { Statements distribution }\end{array}$} & \multicolumn{6}{|c|}{ Grandfather - (9) Father-side } & \multicolumn{6}{|c|}{ Grandfather - (10) Mother-side } \\
\hline & & \multicolumn{2}{|c|}{ Total (67) } & \multicolumn{2}{|c|}{ M-D (34) } & \multicolumn{2}{|c|}{ F-D (33) } & \multicolumn{2}{|c|}{ Total } & \multicolumn{2}{|c|}{ M-D (34) } & \multicolumn{2}{|c|}{ F-D (33) } \\
\hline & & $\mathrm{N}$ & $\%$ & $\mathrm{n}$ & $\%$ & $\mathrm{n}$ & $\%$ & $\mathrm{~N}$ & $\%$ & $\mathrm{n}$ & $\%$ & $\mathrm{n}$ & $\%$ \\
\hline 1. & Hi was an analphabetic & 1 & 1.49 & 1 & 2.94 & - & - & 2 & 2.98 & 1 & 2.94 & 1 & 3.03 \\
\hline 2. & Hi was grammar don't attend school & 3 & 4.47 & 2 & 5.88 & 1 & 3.03 & 4 & 5.97 & 1 & 2.94 & 3 & 9.09 \\
\hline 3. & Complete Primary school & 17 & 25.37 & 7 & 20.59 & 10 & 30.30 & 10 & 14.92 & 5 & 14.71 & 5 & 15.15 \\
\hline 4. & Complete craft & 17 & 25.37 & 11 & 32.35 & 6 & 18.18 & 21 & 31.34 & 12 & 35.29 & 9 & 27.27 \\
\hline 5. & Complete secondary school & 9 & 13.43 & 4 & 11.76 & 5 & 15.15 & 6 & 8.95 & 2 & 5.88 & 4 & 12.12 \\
\hline 6. & Complete College/High school & 11 & 16.42 & 4 & 11.76 & 7 & 21.21 & 12 & 17.91 & 7 & 20.59 & 5 & 15.15 \\
\hline 7. & Complete Faculty & 8 & 11.94 & 4 & 11.76 & 4 & 12.12 & 11 & 16.42 & 5 & 14.71 & 6 & 18.18 \\
\hline 8. & No response & 1 & 1.49 & 1 & 2.94 & - & - & 1 & 1.49 & 1 & 2.94 & - & - \\
\hline
\end{tabular}

\subsection{The Success in Previous Education}

When considering achieved success in previous school year or education (Table 7), whatever is it concerned with primary or secondary school, or faculty, at a total sample of the Folk-dance dancers (52. 24\%), as well as within subsample of male dancers $(41.17 \%)$, and female dancers $(63.63 \%)$, the most present is statement is on the achieved excellent success (5). It is certainly an important indicator, the second according to frequency of claims, achieved very good success (4) as within the total sample of dancers, as well as within the sub-samples of male and female dancers. These data point to the fact that the members of the folk ensemble were eligible students, and practicing folk dances in their free time do not disturbed successful cope with schoolwork or other family responsibilities, not listed here, but they are certainly present in adult dancers, who were with a $2 / 3$ majority present in the actual sample of the folk-dance dancers, in relation to the other members, who belong to the younger and older adolescents, aged 12-19 y ears old.

Table 7. UGSK-11 - School Success of Folk-Dancers in last study year.

\begin{tabular}{lccccc}
\hline \multicolumn{1}{c}{ Statements } & \multicolumn{1}{c}{ (M) Dancers (34) } & \multicolumn{2}{c}{ (F) Dancers (33) } & TOTAL (67) \\
\hline & $\mathbf{n}$ & $\mathbf{\%}$ & $\mathbf{n}$ & $\mathbf{\%}$ & $\mathbf{f} / \mathbf{\%}$ \\
\hline 3. Good & 4 & 11.76 & 3 & 9.09 & $7 / 10.45 \%$ \\
4. Very good & 13 & 38.23 & 8 & 24.24 & $21 / 31.34 \%$ \\
5. Excellent & 14 & 41.17 & 21 & 63.63 & $35 / 52.24 \%$ \\
6. No answer & 3 & 8.82 & 1 & 3.03 & $4 / 5.97 \%$ \\
\hline
\end{tabular}

Note: There were no responses in items: 1 . No passed a grade; 2. Not satisfactory

\subsection{The Participation in Some Others Sports Activities}

Interestingly perceives answers of folk-dance dancer's (presented in Table 8), which are relative to the statements on frequency and modalities of the participation in some other form of sports activities so far!? The most often answers of the respondents, as in the total sample (46.27\%), and within the sub-samples of male dancers ( $38.2 \%$ ), as well as female dancers $(54.5 \%)$ have practiced a sport activity only recreationally (1). On the total sample of the folk-dance dancers $(16.4 \%)$, as well as in the context of sub-sample of male dancers $(17.64 \%)$ the second most common statement was as the active participation on the municipal or regional level (3), although in a male dancers are equally presented other responses $(2,4,5)$ with $14.64 \%$. The female dancers are equally $(15.15 \%)$ opt for the statements in regard the activity within the school sport clubs (2) and taking part in competitions in the community or regional level (3), while the other items are underrepresented.

Table 8. SPAK-12 - Other kind of Folk-Dance Dancers sport activity.

\begin{tabular}{|c|c|c|c|c|c|}
\hline \multirow{2}{*}{$\begin{array}{l}\text { Total / Sub-samples } \\
\text { Statements distribution }\end{array}$} & \multicolumn{2}{|c|}{ M-D (34) } & \multicolumn{2}{|c|}{ F-D (33) } & \multirow{2}{*}{$\begin{array}{l}\begin{array}{l}\text { TOTAL } \\
(67)\end{array} \\
(n / \%)\end{array}$} \\
\hline & $\mathbf{n}$ & $\%$ & $\mathbf{n}$ & $\%$ & \\
\hline $\begin{array}{l}\text { 1. I was engage in sport only } \\
\text { recreate }\end{array}$ & 13 & 38.23 & 18 & 54.54 & $\begin{array}{c}31 \\
(46.27 \%)\end{array}$ \\
\hline $\begin{array}{l}\text { 2. I was active competitor in } \\
\text { school sport club }\end{array}$ & 5 & 14.71 & 5 & 15.15 & $\begin{array}{c}10 \\
(14.92 \%)\end{array}$ \\
\hline $\begin{array}{l}\text { 3. I was active community or } \\
\text { regional level }\end{array}$ & 6 & 17.64 & 5 & 15.15 & $\begin{array}{c}11 \\
(16.42 \%)\end{array}$ \\
\hline $\begin{array}{l}\text { 4. I was active engage in sport } \\
\text { competition on republic level }\end{array}$ & 5 & 14.71 & 3 & 9.09 & $8(11.94 \%)$ \\
\hline $\begin{array}{l}\text { 5. Engage in competitive sport } \\
\text { on state/international level }\end{array}$ & 5 & 14.71 & 1 & 3.03 & $6(8.95 \%)$ \\
\hline No answer & - & - & 1 & 3.03 & $1(1.49 \%)$ \\
\hline
\end{tabular}

\subsection{The Characteristics of the Place of Residency}

In Tables 9A (Male-Dancers) and Table 9B (FemaleDancers) are presented the replies of respondents in regard of the place of residency characteristics, in which subjects (Folk-Dance dancers), and their parents spent his early childhood, up to 15 years of age.

The highest percentage of male dancers $(61.76 \%)$, and their close family members: father (55.88), mother (50\%) are lived in the city where is the headquarters of the district court (3), while the second most common statement was that they lived in the countryside or a small town, without post office (1): mother (29.41\%); father (26.47\%), dancers $(20.59 \%)$.

The highest percentage of female dancers $(42.42 \%)$, and their close family members: mother $(45.45 \%)$ lived in the city where is the headquarters of the district court (3), and father $(33.33 \%)$ lived in a small town, or town with post office (2), while the second most common statement was that they lived in a small city or town with a post office (2) mother (27.27\%); father (30.30\%), dancers (39.3 9\%). 
Table 9A. MTOM (13, 14, 15) Type of city where You, Your Father/Mother spend childhood until age 15.

\begin{tabular}{|c|c|c|c|c|c|c|c|c|c|}
\hline & \multirow{2}{*}{$\begin{array}{c}\text { Sample (Male Dancers) } \\
\text { Abs./Rel. Freq. }\end{array}$} & \multicolumn{2}{|c|}{ Yourself (34) } & \multicolumn{2}{|c|}{ Father (34) } & \multicolumn{2}{|c|}{ Mother (34) } & \multicolumn{2}{|c|}{ Total (68) } \\
\hline & & $\mathbf{n}$ & $\%$ & $\mathbf{n}$ & $\%$ & $\mathbf{n}$ & $\%$ & $\mathbf{N}$ & $\%$ \\
\hline 1 & Village, or small town, without post office & 7 & 20.59 & 9 & 26.47 & 10 & 29.41 & 19 & 27.94 \\
\hline 2 & Small town or city with post office & 3 & 8.82 & 4 & 11.76 & 4 & 11.76 & 8 & 11.76 \\
\hline 3 & Town with county court & 21 & 61.76 & 19 & 55.88 & 17 & 50 & 36 & 52.94 \\
\hline 4 & Republic or Province Center & 3 & 8.82 & 2 & 5.88 & 3 & 8.82 & 5 & 7.35 \\
\hline
\end{tabular}

Table 9B. MTOM (13, 14, 15). Type of city where You, Your Father/Mother spend childhood until age 15.

\begin{tabular}{|c|c|c|c|c|c|c|c|c|c|}
\hline & \multirow{2}{*}{$\begin{array}{c}\text { Sample (Female Dancers) } \\
\text { Abs./Rel. Freq. } \\
\end{array}$} & \multicolumn{2}{|c|}{ Yourself (33) } & \multicolumn{2}{|c|}{ Father (33) } & \multicolumn{2}{|c|}{ Mother (33) } & \multicolumn{2}{|c|}{ Total (66) } \\
\hline & & $\mathbf{n}$ & $\%$ & n & $\%$ & n & $\%$ & $\mathbf{N}$ & $\%$ \\
\hline 1 & Village, or small town, without post office & 1 & 3.03 & 9 & 27.27 & 6 & 18.18 & 15 & 22.72 \\
\hline 2 & Small town or city with post office & 13 & 39.39 & 11 & 33.33 & 9 & 27.27 & 20 & 30.30 \\
\hline 3 & Town with county court & 14 & 42.42 & 10 & 30.30 & 15 & 45.45 & 25 & 37.87 \\
\hline 4 & Republic or Province Center & 5 & 15.15 & 3 & 9.09 & 3 & $9.09 \%$ & 6 & 9.09 \\
\hline
\end{tabular}

\section{Conclusions}

- Based on the research conducted on the total sample of the folk dance dancers $(\mathrm{N}=71)$, aged up 12-40 years old, distributed within four age categories, a total of 34 subjects $(47.9 \%)$ were males $(\mathrm{M})$, average age of 14.3 39.3 years, while 37 respondents $(52.1 \%)$ were female $(\mathrm{F})$, the average age of 16-35 years. Large differences in age points to the fact that the subjects have already in early adolescence been included to the folklore activity content in their free time, but also on the long time period of participation, within these activities, although this information is only indirect, since he was not present as a separate item in the provided statements to the respondents.

- Collected numerical data on the respondents parents education level indicate that in both (father, mother) are prevailing, as in total sample $(63.6 \%)$, as well in subsample of male dancers (36.36\%) and female dancers (27.27\%) completed a 4-year of vocational school for non-productive occupations, although is the second by frequency of statements university parental education, and it is evident that mothers have a higher level of education, compared to fathers, when they perceive a total data on higher and university education, in both male/female sub-sample the folk-dance dancers.

- Pronouncement of respondents in terms of foreign language proficiency indicates that more than $50 \%$ have knowledge of a foreign language, as in male dancers (55. 9\%), as well as in female dancers (63.6\%), although it is interesting the fact that about $1 / 3$ of the respondents who have knowledge of two foreign languages, relatively more present among female dancers $(33.3 \%)$ than in male dancers $(29.4 \%)$. This information may indirectly suggests that folk dance dancers are often traveling abroad, which further inspired them to learn foreign languages, and motivate for more active presence in the folklore ensemble.

- When we look at knowledge of foreign languages among parents, the identical number of cases in fathers, as for male dancers, and female dancers (55.88\%) do not have knowledge of a foreign language, as well as among mothers of female dancers (48.5\%), even though the mothers of female dancers possess knowledge of one foreign language $(48.48 \%)$. This indirectly indicates a positive and stimulating cultural environment of the family of dancers, as well as the dominant role of the mother in this context.

- Considering the educational level of respondents in total sample, and by sub-samples, overall is the most common completed secondary school (gymnasia), although more in a female dancers $(55.9 \%)$, than with male dancers $(38.2 \%)$, and the significant number of dancers attended only primary school $(22.06 \%)$, more in male dancers $(32.35 \%)$ than in female dancers $(11.76 \%)$.

- Provided data on academic achievement indirectly indicate that the members of the AKUD folk ensemble were eligible students that practicing folk-dances in their free time do not disturbed successful cope with school or other family obligations, not listed here, but they are necessary present in group of adult dancers, who were prevailed (with 2/3 majority) in the current sample of dancers, in relation to the others $(1 / 3)$, which fall into the category of younger, and older adolescents, up 12-19 years of age.

- Considering the qualification of parents, there is noticed a large diversity, according to individual items, which were 13 in total. Relatively is the most represented (20.6\%) unemployment rate of mothers within subsample of male-dancers, with an equal number $(17.65 \%)$ of professional and highly skilled workers, and those with higher education in public service, with the father's occupation, then followed with the occupation worker with a university degree, which is represented with $11.76 \%$. Within the sample was the most common occupation highly qualified worker (24.2\%), though here present great variety of options by responses, which indirectly points to the fact that the qualification acquired in previous education, are not in close relation with actual, or recognized qualifications, 
viewed in terms of parents' occupation.

- Considering the grandfather degree of Education, by father-side, in total sample were identically $(25.37 \%)$ presented statements on completion of primary school, or completed craft, although in a sub-sample of male dancers is the most represented the statement on $(32.35 \%)$ completed trade, and in the sub-sample of female dancers on completion of primary school $(30.30 \%)$. In sub-sample of the female dancers is more significant statement (by the frequency of responses) that about the completion of high school of paternal grandfather $(21.21 \%)$.

- Considering the grandfather degree of Education, by mother-side the most often statement is on completed craft in a total sample $(31.34 \%)$, within the sub-sample of male dancers $(35.29 \%)$, and female dancers (27.27\%). Another option, according to the most frequent statements in total sample $(17.91 \%)$, and the sub-sample of male dancers $(20.59 \%)$ was completed college, while in the sub-sample of the female dancers (in $18.18 \%$ ) appear answer on university degree. Analyzing these relative values, without application of advanced comparative methods, and statistical procedures, it is only possible to highlight information which is imposed indirectly, that is also here present relatively higher educational level of the grandfather by father-side, and grandfather mother-side within the subsample of female dancers.

- Interestingly perceives answers of respondents, which are in regard to the frequency of the statements about the practicing some other type of sports activities. The largest number of respondents, as in total sample $(46.27 \%)$, as well as in sub-samples of male dancers $(38.2 \%)$, and female dancers $(54.5 \%)$, are practiced only recreational sports activity. In total sample $(16.4 \%)$, as well as in the context of sub-sample of male dancers $(17.64 \%)$, the second most common response was the active participation on the municipal or regional level, although the male dancers identical were opted for the other responds (14.6\%).

- Female dancers equally (15.15\%) opt for items that include sports activities within the school extracurricular sessions, and participation in the competition at the municipal and regional level, while the other items are underrepresented. These responses indirectly point to the fact that a female dancers were not significantly involved in the competitive sport activities of the higher rank, and such involvement were present only sporadically within the sub-sample of male dancers.

- The highest percentage of male-dancers (61.76\%) and their close family members: father (55.88), mother $(50 \%)$ are lived in the city where is the headquarters of the district court, while the second most common statement was that they lived in the countryside or a small town, without the post office: mother (29.41\%); father $(26.47 \%)$, folk-dance dancers $(20.59 \%)$.

- The highest percentage of female dancers (42.42\%) and their close family members: mother (45.45\%) are lived in the city where is the headquarters of the district court, and father in a small town or city with a post office $(33.33 \%)$. The second most common opt statements in female dancers (39.3 9\%) was that they have lived in a small town or city with a post office: mother $(27.27 \%)$; fathers second option was town with county court $(30.30 \%)$. These data can only indirectly indicate the level of migration of rural families to the smaller towns or city, with the possible supposition that mothers are more willing to change the place of residence, in comparison to the fathers, which may be a coincidence, but in regard of the tradition, and maintenance protection of patriarchal family values, and customs in our country, and region-wide.

- In line with predictions, social identification was significantly related to, and mediated the relationship between family group factors and individual well-being. The special issues as whole points to the capacity for a social identity approach to enrich academic understanding in these areas and provide a bridge between social psychological concepts and the economic and educational domains. On the base of results analysis and previous researches it is possible to collect very important information for further studies with similar issues in the social domain.

\section{References}

[1] Balter Blume, L. (2003). Embodied [by] Dance: adolescent $\mathrm{de} /$ constructions of body, sex and gender in physical education. Sex Education, Volume 3, Issue 2: pages 95-103.

[2] Bannon, F., Sanderson, P. (2000). Experience Every Moment: aesthetically significant dance education. Research in Dance Education, Volume 1, Issue 1: pages 9-26.

[3] Craine, D., Mackrell, J. (2010). The Oxford Dictionary of Dance. Second Edition. OXFORD University Press.

[4] Hirota, VB, Sousa, FAX., Pires, S., Sousa, C. (2013). Preliminary Steps validation instrument for ballet and jazz practitioners. Physical Education Journal, 7 (3): 46-55.

[5] Hirota, et al. (2015). Achievement Goals Orientation of Brazilian Participants of a Dance Festival. International Journal of Sports and Physical Education (IJSPE), 1 (1): 29-34.

[6] Hošek, A., Petrović, K., Momirović, K., Horga, S. (1982). Relations between sports and some factors influencing the socialization process. International Review of Sport Sociology, 4 (17): 39-46.

[7] Koff, S. (2005). Dance Education as an Aspect of Movement and Mobility in Everyday Living. QUEST, 57 (1): February

[8] Kocić, J., Popović, J., Tošić, S. (2010). Modern dance in the function of public performance and health protecting. 2nd International Scientific Conference »Anthropological Aspects of Sports, Physical Education and Recreation«, Banja Luka, November 2010. Book of Summaries, pp. 91-92, Faculty of Physical Education and Sports: University of Banja Luka. ISSN 1986-8146. 
[9] Meakin, D. C., Sanderson, P. (1983). Dance in English Secondary Schools Today. Journal of Aesthetic Education, Vol. 17 (1): 69-83.

[10] Motta, MAM, Motta, SM, Liberali, R. (2012). The Motivation and the self-esteem of teenagers in a dance project. Mackenzie Journal of Physical Education and Sport 11 (2): 55-67.

[11] Mutavdžić, V. (1999). Factor structure of dance patterns in folk dances of Serbia. (Faktorska struktura plesnih obrazaca narodnih plesova Srbije) (unpublished $\mathrm{PhD}$ thesis), [in SerboCroatian]. University of Pristine: Faculty of Physical Culture, Leposavić, Kosovo, Serbia.

[12] Mutavdžić, V. (2007). Factor structure of dance patterns in folk dances of Serbia. Serbian Journal of Sports Sciences, 1, (131-138), Belgrade, Serbia.

[13] Petrović, K., Hošek, A. (1986). Contribution to Sociology of Sport. Prilozi za Sociologiju sporta. Knjiga 1. (in SerboCroatian). Fakultet za fizičku kulturu, Sveučilišta u Zagrebu.

[14] Petrović, K., Hošek, A. (1986). Contribution to Sociology of Sport. Prilozi za Sociologiju sporta. Knjiga 2. (in SerboCroatian). Fakultet za fizičku kulturu, Sveučilišta u Zagrebu.

[15] Popović, J. (2009). The structure of anthropological dimensions of dancers. Struktura antropoloških dimenzija plesača. (unpublished master thesis), (in Serbo-Croatian). Fakultet za fizičku kulturu, Leposavić, Univerzitet u Prištini/Kos. Mitrovica, Kosovo, Srbija.

[16] Popović, J. (2010). The structure of anthropological dimensions of Folk dance dancers, both male and female. Struktura antropoloških dimenzija plesača $i$ plesačica narodnih plesova. (unpublished $\mathrm{PhD}$ thesis), (in SerboCroatian). Fakultet Sporta i Fizičkog vaspitanja, Leposavić, Univerzitet u Prištini/Kosovska Mitrovica, Kosovo, Srbija.

[17] Popovic, R., Djordjevic, I., Dolga, M., Purenovic, T., Pavlovic, M. (2009). Demographic differences in Statements on Folk and Social Dance in Elementary School-girls. In: Ed.: Marie Blahutkova, Proceedings of Abstracts (p.101). International Conference ,,Sport and Quality of Life” - 2009, November 5-6, 2009, Brno (Czech Republic), ISBN 978-80210-5006-8.

[18] Popović, M., Dolga, M., Popović,, J., Popović, R. (2009). Satisfaction with Extra-Curricular Sport Activities of UpperElementary and Secondary School Adolescents. In: Eds.: V. Poč, E, Matejkova, Proceedings of Abstracts p. 24. 3rd International Students' Science Conference in Kinanthropology, Brno Universitas Masarykiana, Facultas Artis Gymnasticae Sportivae. ISBN 978-80-210-4839-3.

[19] Popovic, M., Popovic, R., Dolga, M., Popovic, J. (2011). The Analysis of the Gender and Age Specific Attitudes Toward the Elective Sport Among Adolescents. Scientific Congress Research \& Applications in Sport Science," Abstracts Book, National and Kapodistrian University of Athens Department of Physical Education \& Sports Science (May 6-8, 2011).

[20] Popović, R. (1997). Rhythmic and Dances in Physical Education - Sport - Recreation - Kinesitherapy. Ritmika $i$ Plesovi u Fizičkom vaspitanju - Sportu - Rekreaciji Kineziterapiji. (in Serbo-Croatian). Centar za multidisciplinarna istraživanja Fakulteta za fizičku kulturu Univerziteta u Prištini. YU ISBN 86-82329-07-7
[21] Popović, R., Dolga, M., Popović J. (2007): Presentation and analysis of the elementary school students toward the elective sport. Prikaz i analiza stavova učenika osnovnih škola prema izbornom sportu. (in Serbo-Croatian). 15th International Interdisciplinary Symposium «Ecology, Sport, Physical Activities and Health of Youth», Program and Summary, Eds.: B. Krsmanović, T. Halaši, pp. 11-12, Novi Sad, Serbia (11-14 October, 2007). ISBN 978-86-8602-07-4.

[22] Popović, R., Đorđević, I., Popović, J. (2009). Music and movement as a means of the psycho-motor development stimulation in pre-school children. In: Eds. B. Krsmanović, T. Halaši, M. Dolga, Summary, pp. 13-15, 17th International Interdisciplinary Symposium ,Ecology, Sport, Physical activities and Health of Youth», Novi Sad, Serbia (October 89, 2009), ISBN 978-86-86025-10-4.

[23] Popović, R., Levajac, R., Kocić, J., Popović J. (2008). Estimation of the Elementary school boys and girls attitudes to art-dance. Ispitivanje stavova prema plesnoj umetnosti kod učenika osnovne škole različitog pola i uzrasta. (in SerboCroatian). "Umetnost u metodikama nastave», Univerzitet $\mathrm{u}$ Kragujevcu, Pedagoški fakultet (11-12. April, 2008) Jagodina, Srbija (Plenary lecture, in manuscript).

[24] Popović, R., Nikolić, V., Dolga, M., Popović, J. (2008). Estimation of the Secondary school student's attitudes toward various aspects of dance activities. Ispitivanje stavova prema različitim aspektima plesne aktivnosti kod učenika srednje škole. (in Serbo-Croatian). XVI međunarodni multidisciplinarni simpozijum Ecology, Sport, Physical Activities and Health of Youth," Program and Summary, Eds.: B. Krsmanović, T. Halaši (pp. 111-112), Novi Sad, Srbija (9-12. October, 2008), ISBN 978-86-8602$07-4$.

[25] Popović, R., Popović, J. \& Đorđević, I. (2009). Teaching Dances and Rhythmic gymnastics: A Developmentally Appropriate Approach. In: Eds. B. Krsmanović, T. Halaši, M. Dolga, Summary, pp. 15-16, 17th International Interdisciplinary Symposium „Ecology, Sport, Physical activities and Health of Youth», Novi Sad, October 8-9, 2009. ISBN 978-86-86025-10-4.

[26] Popović, R., Popović, J. \& Đorđević, I. (2009). Age and demographic differences in statements on Folk and Social dance in the primary school-girls. In: Eds.: B. Krsmanović, T. Halaši, M. Dolga, Summary (p. 76), 17th International Interdisciplinary Symposium ,Ecology, Sport, Physical activities and Health of Youth», Novi Sad, October 8-9, 2009. ISBN 978-86-86025-10-4.

[27] Popović, R., Popović, M., \& Popović, J. (2014). The analysis of the gender and age specific attitudes toward the elective sport among children and youth. Conference Proceedings of 4th Annual International Scientific Conference „Sapere Aude 2014 - Pedagogy, Psychology and Today World", (pp. 536546). March, 24-28, 2014, Hradec Králové (CZ): MAGNANIMITAS. Vol. IV. ISBN 978-80-87952-03-0, ETTN 085-14-14029-03-1.

[28] Popović, R., Purenović, T. (2009). Social identity and status characteristics of physical education female students and family members in manifest stratification dimensions. In: PROCEEDINGS, Ed.: N. Živanović, pp. 745-749, 5th FIEP European congress and 2nd Serbian congress of Physical Education Teachers, September 23-26, 2009, Nis (Serbia). ISBN 978-86-83811-15-1, COBISS. SR-ID 174203148. 
[29] Popovic R., Purenovic T., Dolga M., Pavlovic M., Tzurova R. (2008). Age and Demographic Differences in Attitudes towards Art Dance in the Primary School-Girls from the Region of Valjevo in Serbia. In: SPORT \& SCIENCE "Topical problems of physical culture", I part, pp. 195-203, Cheirman of the Board of eds: Lj. Dimitrov, National Sports Academy »V. Levsky«: Sofia (Bulgaria), ISSN 1310-3393.

[30] Popović, R., Purenović-Ivanović, T., Dolga, M., Pavlović, M. (2012). Application of folk \& social dance attitude scales in adolescent girls and rhythmic gymnasts. In: Đ. Miletić, S. Krstulović, Z. Grgantov, T. Bavčević, A. Kezić (Eds.), Proceedings book of $4^{\text {th }}$ International scientific conference “Contemporary Kinesiology”, (pp. 572-581). August, 24-26, 2012, Split: Faculty of Kinesiology, University of Split, Croatia. ISSN 1847-0149.

[31] Risner, D. (2007). Rehearsing masculinity: challenging the 'boy code' in dance education. Research in Dance Education, Volume 8 , Issue 2: pages $139-153$.

[32] Saksida, S., Caserman, A., Petrović, K. (1974). Social stratification and mobility in Yugoslav society. $8^{\text {th }}$ World Congress of ISA, Toronto (pp. 213-363).

[33] Saksida, S., Knap, Ž. (1970). An example of the mathematical model quantification in regard of the social stratification analysis. Poskus kvantifikacije matematičnega modela za analizo socialne stratifikacije. (in Slovene). Ljubljana: Institut za sociologijo in filozofijo.

[34] Saksida, S., Momirović, K., Petrović, K. (1972). Theoretical model of social stratification. Teoretični model socialne stratifikacije. (in Slovene). Teorija in praksa, 9 (4), 14071419.

[35] Saksida, S., Petrović, K. (1973). Numerical-taxonomical classification of the social groups. Numeričko-taksonomska klasifikacija družbenih grupa-faktorska analiza. (in Slovene). Ljubljana: Institut za sociologijo in filozofijo.

[36] Sanderson, P. (2000). 'The Development of Dance Attitude Scales', Educational Research, 42 (1): 91-99.

[37] Sanderson, P. (2001). Age and Gender Issues in Adolescent Attitudes to Dance. European Physical Education Review, Vol. 7, No. 2: 117-136.

[38] Sanderson, P. (2007). The arts, social inclusion and social class: the case of dance. British Educational Research Journal (accessed in November, 2007).

[39] Sanderson, P. (2009). The development of dance attitude scales. Educational Research, Volume 42, Issue 1: 91-99.

[40] Vicario, T., Chambliss, C. (2001). The Benefits Associated with Dance Education for Adolescent Girls. (accessed in 2001).

[41] Wikipedia, the free encyclopedia (downloaded in December, 2016).

[42] World Health Organization - WHO (2002). World Medical Association Declaration of Helsinki, Ethical Principles for Medical Research Involving Human Subjects. Bulletin of the WHO, 79 (4). 